\title{
Penyuluhan Protozoa Usus Penyebab Diare dan Penyerahan Washtafel Pada Siswa SD Makamhaji 03 Sukoharjo
}

\author{
${ }^{1)}$ Rochmadina Suci Bestari, ${ }^{2)}$ Novita Ardilla, ${ }^{3)}$ Safitri Sri Handayani \\ Prodi Pendidikan Dokter, Fakultas Kedokteran, Universitas Muhammadiyah Surakarta \\ email : rsb156@ums.ac.id
}

\begin{abstract}
ABSTRAK
Penyakit diare merupakan penyakit endemis di Indonesia. Pada tahun 2016 terdapat 911.901 kejadian diare di Jawa Tengah. Salah satu sebab diare adalah infeksi protozoa usus. Penyakit diare yang disebabkan oleh protozoa usus pada siswa SD bisa terjadi karena banyak faktor, antara lain yaitu pengetahuan dan sikap tentang protozoa usus yang bisa menyebabkan diare, serta perilaku dalam pencegahan diare karena protozoa usus. Perilaku dalam hal ini yang bisa mencegah terjadinya diare karena protozoa usus yaitu menjaga personal higiene siswa, misalnya mencuci tangan sebelum makan dan sesudah buang air besar. Oleh karena itu, kami mengadakan pengabdian masyarakat dengan cara memberikan penyuluhan tentang protozoa usus yang bisa menyebabkan diare kepada siswa-siswi SD Makamhaji 03 Sukoharjo. Tujuan pengabdian masyarakat ini adalah untuk memberi pengetahuan kepada siswa-siswi SD Makamhaji 03 Sukoharjo tentang protozoa usus yang dapat menyebabkan diare. Kegiatan pengabdian masyarakat ini dilaksanakan pada hari Rabu tanggal 13 November 2019 di SD Negeri Makamhaji 03 Kartasura Kabupaten Sukoharjo. Peserta penyuluhan terdiri dari siswasiswi kelas IV, sebanyak 37 anak. Siswa-siswi mengikuti penyuluhan dengan antusias. Acara ditutup dengan penyerahan washtafel dan sabun cuci tangan dari tim penyuluh kepada pihak sekolah. Persiapan, proses dan hasil penyuluhan baik. Terdapat peningkatan pengetahuan siswa tentang protozoa sebagai penyebab diare. Hal tersebut bisa diketahui dari nilai kuesioner. Ratarata nilai pretes adalah 2,45 sedangkan rata-rata nilai postes adalah 3,16 .
\end{abstract}

Kata kunci : diare, penyuluhan, protozoa usus

\begin{abstract}
Diarrhea is an endemic disease in Indonesia. On 2016, the incidence of diarrhea was 911.901 cases in Central Java. One of microorganism can cause diarrhea is intestinal protozoa. Protozoal diarrhea in elementry school students can occur because of many factors, such as knowledge and attitude of the diarrheal prevention. One of the attitudes is about maintain personal hygiene, such as washing hands before and after eating and after defecation. We did the community service by socialization to the students about intestinal protozoa as cause of diarrhea. The socialization aimed to give adequat information about intestinal protozoa as cause of diarrhea to the students of SD Makamhaji 03 Sukoharjo. The community service was held on Wednesday, $13^{\text {th }}$ November 2019 in SD Makamhaji 03 Sukoharjo. The audience was students of $4^{\text {th }}$ grade of SD Makamhaji 03 Sukoharjo, 37 students. The students attended the socialization well. There was donation of washtafel and hand soap from presenter team to school team. The preparation, process and socialization result was good. There was increasing of students' knowledge about intestinal protozoa as cause of diarrhea, within the mean of pretest score was 2.45 meanwhile the mean of postes score was 3.16.
\end{abstract}

Keywords : socialization, diarrhea, intestinal protozoa 
AS-SYIFA: Jurnal Pengabdian

dan Pemberdayaan Kesehatan

Masyarakat

\section{PENDAHULUAN}

Penyakit diare merupakan penyakit endemis di Indonesia. Diare sendiri diartikan sebagai peningkatan frekuensi buang air besar yang lebih dari tiga kali sehari. Diare menyebabkan seseorang kekurangan cairan dan elektrolit, jika tidak tertangani dengan baik, diare berat bisa menyebabkan kematian.

Pada tahun 2016 terdapat 911.901 kejadian diare di Jawa tengah dan hanya 95.635 kasus yang tertangani (Kemenkes RI, 2016). Sementara itu, jumlah kasus diare di Kabupaten Sukoharjo tahun 2011 sebanyak 22.971 penderita (Dinkes Sukoharjo, 2011).

Salah satu penyebab diare adalah infeksi protozoa usus. Protozoa usus adalah parasit bersel satu yang habitatnya di usus. Beberapa spesies bisa menjadi penyebab, yaitu Entamoeba histolytica, Balantidium coli, Giardia lamblia. Berturut-turut terjadi penyakit Amebiasis, Balantidiasis, Giardiasis. Gejalanya diare dengan manifestasi bervariasi (Rusmartini, 2009; Artika dkk, 2017, Soedarto, 2011, Geoffrey et al., 2002; Abasian et al., 2013, Meningher et al., 2019; Schuster dan Ramirez-Avila, 2008).

Penyakit diare yang disebabkan oleh protozoa usus pada siswa SD bisa terjadi karena banyak faktor, antara lain berhubungan dengan sanitasi yang kurang baik, tingkat pendidikan dan sosial ekonomi yang rendah. Pemindahan (transmisi) parasit ini dipengaruhi oleh banyak faktor, antara lain faktor parasitnya, iklim, lalat, dan lipas, tuan rumah reservoir, pupuk tanaman dan tinja manusia, penyaji makanan, kepadatan penduduk, dan faktor lainnya (Rusmartini, 2009; Artika dkk, 2017).

Pencegahan untuk penyakit ini dapat dilakukan melalui berbagai cara., yaitu mengobati penderita, pendidikan kesehatan terutama menyangkut kebersihan, baik hygiene perorangan maupun sanitasi lingkungan meliputi sumber air, tempat sampah, pembuangan tinja. Selain itu adalah pemberantasan lalat dan kecoa yang bisa berperan sebagai vektor mekanik (Rusmartini, 2009; Rina, 2017, Soetanto dkk, 2011; Maryatun, 2008, Vivancos et al., 2018).

Dalam hal pendidikan kesehatan untuk siswa, faktor yang berpengaruh yaitu pengetahuan dan sikap tentang diare yang disebabkan oleh protozoa usus serta perilaku terhadap pencegahan diare. Perilaku dalam hal ini yang bisa mencegah terjadinya diare karena protozoa usus yaitu menjaga personal higiene siswa, yaitu mencuci tangan sebelum dan sesudah makan, mencuci tangan setelah buang air besar (BAB), memakai alas kaki saat bermain di tanah, memotong kuku satu minggu sekali (Rusmartini, 2009).

SD Makamhaji 03 Sukoharjo adalah salah satu Sekolah Dasar di Sukoharjo yang daerah sekitarnya masih banyak terdapat tanah lembab, yang bisa menjadi sarana pertumbuhan kista protozoa usus sebagai penyebab diare. Di tengah sekolah terdapat lapangan yang digunakan untuk kegiatan di luar ruangan, misalnya upacara, olahraga, pelajaran penjas. Selain itu, siswa-siswi yang menunggu jemputan di siang hari maupun sore hari menggunakan area ini sambil bermain dan terkadang melepas alas kaki. Sehingga bisa dilihat bahwa permasalahan yang dihadapi adalah perilaku siswa yang berisiko terkena sakit diare.

Untuk mencegah diare karena protozoa usus pada siswa, seyogyanya dilakukan usaha pengobatan dan promosi kesehatan yang disesuaikan dengan penerimaan siswa, yaitu dengan penyuluhan. Setelah mendapatkan penyuluhan, diharapkan 
siswa-siswi memahami dan meningkat pengetahuannya tentang diare dan protozoa usus.

\section{METODE}

Kegiatan Penyuluhan "Protozoa Usus Penyebab Diare kepada Siswa-siswi SD Negeri Makamhaji 03 Sukoharjo" dilaksanakan pada hari Rabu, 13 November 2019 pukul 09.00-12.00 WIB di Ruang kelas IV SD Negeri Makamhaji 03 Sukoharjo. Kegiatan diikuti oleh 37 siswa.

Metode yang dipakai adalah pretes-postes dan pemaparan materi. Kegiatan diawali dengan pembukaan oleh tim penyuluh dan pengantar oleh guru kelas. Pretes terdiri dari 4 pertanyaan multiple choice. Lembar jawab dibagikan kepada para siswa. Para siswa diminta menjawab sesuai pengetahuan masing-masing selama 1 menit untuk setiap pertanyaan, dengan memilih jawaban yang benar dari 4 pilihan jawaban. Kemudian pemateri melaksanakan penyuluhan.

Daftar pertanyaan pretes adalah sebagai berikut :

1) Apa yang bisa menyebabkan sakit diare?

a. Makan enak

b. Minum es

c. Pakai baju kotor

d. Bakteri (jawaban benar)

2) Apakah sebaiknya yang kita pakai di lapangan agar terhindar dari penyakit?

a. Sepatu/sandal (jawaban benar)

b. telanjang kaki

c. sepatu boot

d. sandal bersol tinggi

3) Kapankah cuci tangan sebaiknya dilakukan?

a. Sebelum makan

b. Sebelum dan sesudah makan (jawaban benar)

c. Sesudah makan

d. Tidak perlu cuci tangan

4) Termasuk organisme apakah Entamoeba histolytica?

a. Virus

b. Bakteri

c. Parasit (jawaban benar)

d. Serangga

(Kunci jawaban $=\mathrm{d}, \mathrm{a}, \mathrm{b}, \mathrm{c}$, jika betul dinilai 1 , jika salah dinilai 0$)$

Pemateri menjelaskan tentang protozoa usus sebagai penyebab penyakit diare. Siswa-siswi diberi informasi bahwa protozoa usus terdiri dari bermacam-macam jenis, antara lain : Entamoeba histolytica, Balantidium coli dan Giardia lamblia, disertai gambar-gambar parasit tersebut. Gejala diare yang bisa ditimbulkan antara lain sakit perut dan konsistensi tinja yang jelek yaitu lembek dan bisa disertai darah maupun lendir. Penularan dari parasit perut ini bisa dengan berbagai cara, antara lain yaitu bermain lumpur tanpa alas kaki, tidak cuci tangan sebelum dan setelah makan. Pencegahan dapat dilakukan dengan cara : cuci tangan sebelum dan setelah makan, 
cuci tangan setelah buang air besar. Pencegahan lain untuk diare adalah minum obat cacing dan periksa ke dokter jika sakit. Penyampaian materi menggunakan poster.

Setelah pemateri menerangkan hal-hal tersebut, siswa-siswi diberi pertanyaan melalui postes, dengan jumlah dan jenis pertanyaan yang sama dengan pretes. Tim penyuluh juga melakukan demo mencuci tangan dengan standar WHO.

Berikut ini cara mencuci tangan yang baik itu menggunakan sabun dan 7 langkah WHO (World Health Organization) :

1.Basahi tangan dan tuangkan atau oleskan produk sabun di telapak tangan.

2.Tangkupkan kedua telapak tangan dan gosokkan produk sabun yang telah dituangkan.

3.Letakkan telapak tangan kanan di atas punggung tangan kiri dengan jari yang terjalin dan ulangi untuk sebaliknya.

4.Letakkan telapak tangan kanan ke telapak tangan kiri dengan jari saling terkait.

5.Tangan kanan dan kiri saling menggenggam dan jari bertautan agar sabun mengenai kuku dan pangkal jari.

6.Gosok ibu jari kiri dengan menggunakan tangan kanan dan sebaliknya.

7.Gosokkan jari-jari tangan kanan yang tergenggam di telapak tanga kiridan sebaliknya.

Siswa-siswi mengikuti dengan antusias. Hadiah hadir diberikan kepada siswasiswi yang berani praktek cuci tangan di depan kelas.

Kegiatan terakhir adalah penyerahan washtafel (merk AFOS) dan beberapa sabun cuci tangan (merk Dettol) kepada perwakilan Kepala SD Negeri Makamhaji 03 Sukoharjo.

\section{HASIL DAN PEMBAHASAN}

Secara umum, persiapan, proses dan hasil penyuluhan dilaksanakan dengan baik. Hasil Pretes Penyuluhan "Protozoa Usus Penyebab Diare kepada Siswa-siswi SD Negeri Makamhaji 03 Sukoharjo disajikan pada Tabel 1.

Tabel 1. Hasil Pretes Penyuluhan "Protozoa Usus Penyebab Diare kepada Siswa-

\begin{tabular}{llllll}
\hline & Soal & Soal & Soal & Soal & $\begin{array}{l}\text { Jumlah } \\
\text { betul }\end{array}$ \\
No. & $\mathbf{1}$ & $\mathbf{2}$ & $\mathbf{3}$ & $\mathbf{4}$ & 2 \\
1 & 1 & 0 & 1 & 0 & 3 \\
2 & 1 & 1 & 1 & 0 & 3 \\
3 & 0 & 1 & 1 & 1 & 2 \\
4 & 1 & 0 & 1 & 0 & 2 \\
5 & 0 & 0 & 1 & 1 & 4 \\
6 & 1 & 1 & 1 & 1 & 3 \\
7 & 1 & 0 & 1 & 1 & 2 \\
8 & 1 & 0 & 1 & 0 & 3 \\
9 & 1 & 0 & 1 & 1 & 1 \\
10 & 0 & 1 & 0 & 0 & 2 \\
11 & 1 & 0 & 1 & 0 & 3 \\
12 & 1 & 1 & 1 & 0 & 3 \\
13 & 1 & 1 & 1 & 0 & \\
\hline
\end{tabular}


Volume. 1 No. 2 tahun 2020 Nov 2020 - Mei 2021
ISSN (online): 2722-2055 https://jurnal.umj.ac.id/index.php/ASSYIFA
AS-SYIFA: Jurnal Pengabdian dan Pemberdayaan Kesehatan Masyarakat

\begin{tabular}{llllll}
\hline 14 & 1 & 0 & 1 & 0 & 2 \\
15 & 1 & 0 & 0 & 0 & 1 \\
16 & 1 & 0 & 1 & 0 & 2 \\
17 & 1 & 1 & 1 & 0 & 3 \\
18 & 1 & 0 & 1 & 0 & 2 \\
19 & 1 & 1 & 1 & 0 & 3 \\
20 & 1 & 1 & 1 & 0 & 3 \\
21 & 1 & 0 & 1 & 1 & 3 \\
22 & 1 & 1 & 1 & 0 & 3 \\
23 & 0 & 0 & 0 & 1 & 1 \\
24 & 1 & 1 & 1 & 0 & 3 \\
25 & 1 & 0 & 1 & 0 & 2 \\
26 & 1 & 0 & 1 & 0 & 2 \\
27 & 1 & 1 & 1 & 1 & 4 \\
28 & 1 & 1 & 1 & 0 & 3 \\
29 & 1 & 1 & 1 & 1 & 4 \\
30 & 1 & 0 & 1 & 0 & 2 \\
31 & 1 & 1 & 0 & 0 & 2 \\
32 & 1 & 0 & 1 & 0 & 2 \\
33 & 1 & 1 & 1 & 0 & 3 \\
34 & 1 & 1 & 1 & 0 & 3 \\
35 & 1 & 0 & 0 & 0 & 1 \\
36 & 1 & 0 & 1 & 0 & 2 \\
37 & 1 & 0 & 1 & 0 & 2 \\
RATA-RATA & & & & $\mathbf{2 . 4 5 9 4 5 9 4 5 9}$ \\
\hline
\end{tabular}

Setelah diadakan penyuluhan, siswa-siswi mengerjakan postes. Data hasil kuesioner postes disajikan pada Tabel 2.

Tabel 2. Hasil Postes Penyuluhan "Protozoa Usus Penyebab Diare kepada Siswasiswi SD Negeri Makamhaji 03 Sukoharjo"

\begin{tabular}{llllll}
\hline No. & Soal & 1 & Soal 2 & Soal 3 & $\begin{array}{l}\text { Soal } \\
\text { Jumlah } \\
\text { betul }\end{array}$ \\
\hline 1 & 0 & 0 & 1 & 1 & 2 \\
2 & 1 & 0 & 1 & 1 & 3 \\
3 & 1 & 1 & 1 & 1 & 4 \\
4 & 0 & 0 & 0 & 0 & 0 \\
5 & 1 & 1 & 1 & 1 & 4 \\
6 & 1 & 1 & 1 & 1 & 4 \\
7 & 1 & 1 & 1 & 1 & 4 \\
8 & 0 & 0 & 0 & 0 & 0 \\
9 & 1 & 1 & 1 & 1 & 4 \\
10 & 1 & 1 & 1 & 1 & 4 \\
11 & 0 & 1 & 1 & 1 & 3 \\
12 & 1 & 1 & 1 & 1 & 4 \\
\hline
\end{tabular}


Volume. 1 No. 2 tahun 2020 Nov 2020 - Mei 2021
ISSN (online): 2722-2055 https://jurnal.umj.ac.id/index.php/ASSYIFA
AS-SYIFA: Jurnal Pengabdian

dan Pemberdayaan Kesehatan Masyarakat

\begin{tabular}{llllll}
\hline 13 & 1 & 0 & 1 & 1 & 3 \\
14 & 1 & 1 & 1 & 1 & 4 \\
15 & 0 & 1 & 1 & 1 & 3 \\
16 & 1 & 1 & 0 & 1 & 3 \\
17 & 1 & 1 & 1 & 1 & 4 \\
18 & 0 & 0 & 1 & 1 & 2 \\
19 & 0 & 1 & 1 & 1 & 3 \\
20 & 1 & 1 & 1 & 1 & 4 \\
21 & 1 & 1 & 1 & 1 & 4 \\
22 & 1 & 0 & 1 & 1 & 3 \\
23 & 1 & 1 & 1 & 1 & 4 \\
24 & 0 & 1 & 1 & 0 & 2 \\
25 & 1 & 1 & 1 & 1 & 4 \\
26 & 1 & 1 & 1 & 1 & 4 \\
27 & 1 & 1 & 1 & 1 & 4 \\
28 & 0 & 1 & 1 & 1 & 3 \\
29 & 1 & 1 & 1 & 1 & 4 \\
30 & 1 & 1 & 1 & 0 & 3 \\
31 & 1 & 1 & 1 & 0 & 3 \\
32 & 1 & 1 & 1 & 0 & 3 \\
33 & 1 & 0 & 1 & 1 & 3 \\
34 & 0 & 0 & 1 & 1 & 2 \\
35 & 0 & 0 & 0 & 1 & 1 \\
36 & 1 & 1 & 1 & 1 & 4 \\
37 & 1 & 1 & 1 & 1 & 4 \\
RATA-RATA & & & & $\mathbf{3 . 1 6 2 1 6 2 1 6 2}$ \\
\hline
\end{tabular}

Dari hasil nilai pretes dan postes, terdapat peningkatan pengetahuan siswa tentang protozoa sebagai penyebab diare. Hal tersebut bisa diketahui dari nilai kuesioner. Rata-rata nilai pretes adalah 2,45 sedangkan rata-rata nilai postes adalah 3,16.

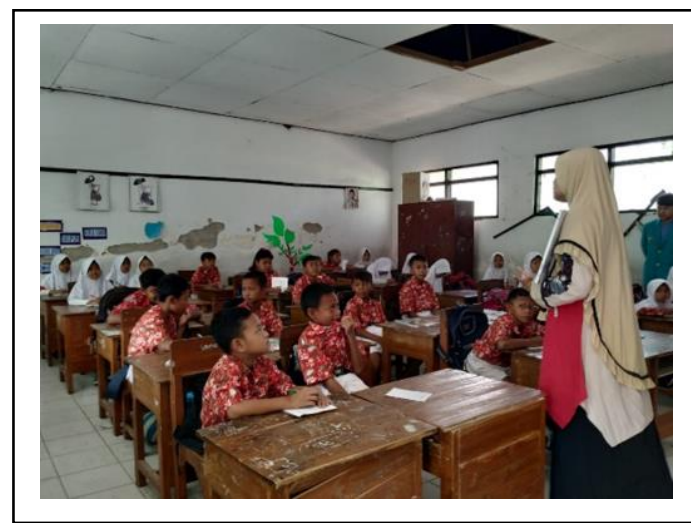

Gambar 1. Penyuluhan "Protozoa Usus Penyebab Diare kepada Siswa-siswi SD Negeri Makamhaji 03 Sukoharjo", pemateri menjelaskan tentang diare, siswa-siswa memperhatikan dengan seksama 


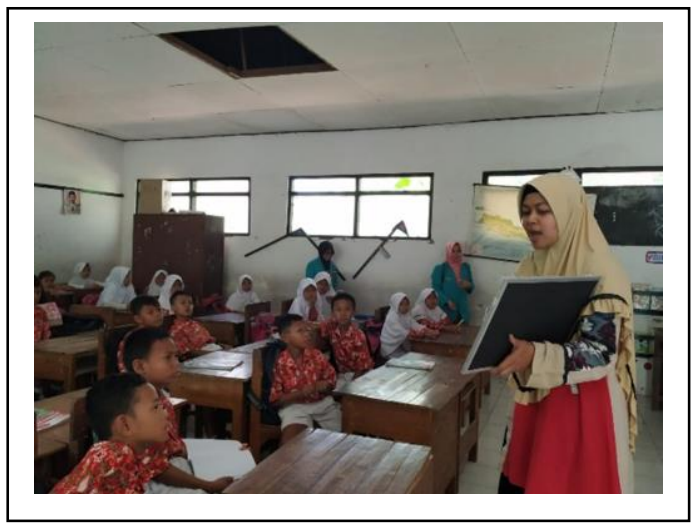

Gambar 2. Penyuluhan "Protozoa Usus Penyebab Diare kepada Siswa-siswi SD Negeri Makamhaji 03 Sukoharjo", pemateri menjelaskan tentang protozoa, siswasiswi memperhatikan dengan baik

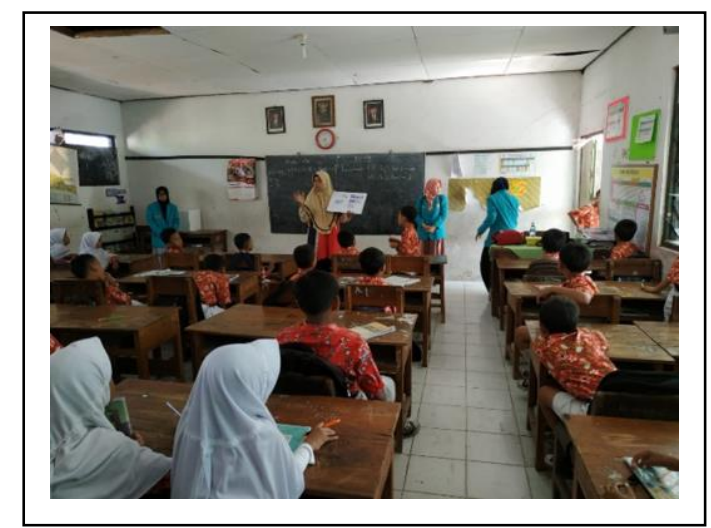

Gambar 3. Penyuluhan "Protozoa Usus Penyebab Diare kepada Siswa-siswi SD Negeri Makamhaji 03 Sukoharjo", tim penyuluh mempersiapkan postes setelah pemaparan materi

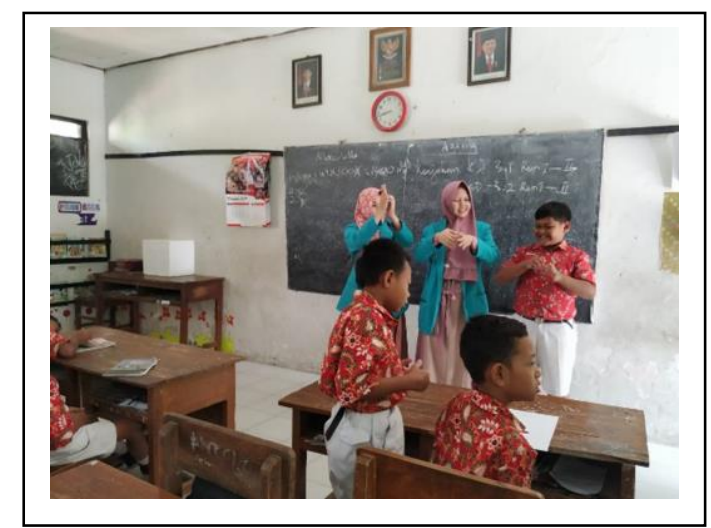

Gambar 4. Penyuluhan "Protozoa Usus Penyebab Diare kepada Siswa-siswi SD Negeri Makamhaji 03 Sukoharjo", tim penyuluh mengajari cara cuci tangan sesuai standar WHO, siswa memperagakan di depan kelas 
Dari hasil pretes dan postes, soal yang paling sulit dijawab oleh siswa adalah nomor 4 yaitu tentang protozoa. Setelah mendapat materi tentang protozoa usus, siswa-siswa bisa menjawab soal nomor 4 pada postes.

Meningkatnya pengetahuan tentang protozoa usus sebagai penyebab diare diharapkan dapat mengubah sikap dan tindakan para siswa menjadi lebih baik lagi untuk mencegah terjadinya penyakit tersebut.

Dari kegiatan simulasi peragaan cuci tangan cara WHO, siswa dapat mengetahui cara mencuci tangan dengan benar untuk mencegah diare. Adanya siswa yang maju ke depan kelas juga memberi semangat teman-temannya untuk memperhatikan dan mempraktekkan.

Kelemahan dari penyuluhan ini adalah siswa-siswi cukup ramai sehingga perlu ditenangkan guru. Kelebihan dari kegiatan ini adalah materi dan penyampaian menarik sehingga siswa-siswi antusias selama mengikuti kegiatan.

\section{KESIMPULAN DAN SARAN}

Penyuluhan "Protozoa Usus Penyebab Diare kepada Siswa-siswi SD Negeri Makamhaji 03 Sukoharjo" telah dilaksanakan dengan baik. Hasil nilai pretes dan postes menunjukkan adanya peningkatan pengetahuan siswa. Penyerahan washtafel dan sabun cuci tangan ke pihak sekolah bermanfaat untuk pencegahan diare bagi siswa.

Saran dari kegiatan ini yaitu adanya tindak lanjut berupa kegiatan serupa dengan kuesioner untuk menggali pengetahuan siswa mengenai protozoa usus sebagai penyebab diare maupun mikroorganisme lain.

\section{UCAPAN TERIMA KASIH}

Pelaksanaan kegiatan pengabdian kolaboratif ini terdapat bantuan dari beberapa pihak. Ucapan terimakasih diberikan kepada Asosiasi Pendidikan Kedokteran dan Kesehatan Muhammadiyah (APKKM) atas hibah pengabdian periode 2019/2020 yang digunakan dalam kegiatan pengabdian masyarakat ini. Selain itu, terimakasih kepada Dekan FK UMS dan Rektor UMS atas kesempatan yang diberikan sehingga memperlancar pelaksanaan kegiatan ini. Terimakasih pula untuk guru-guru dan pimpinan SD Negeri Makamhaji 03 Sukoharjo yang telah banyak membantu untuk terlaksananya kegiatan ini.

\section{REFERENSI}

Abasian, L., Shirbazou, S., Talebi, F., Delpisheh, A. 2013. A meta-analysis of Giardia lamblia in Iran. AJMR vol.7(15), pp. 1343-1348

Artika, M., Nurhayati, Alioes, Y. 2017. Hubungan Kebiasaan Mencuci Tangan dan Memotong Kuku dengan Kejadian Giardiasis Asimtomatik. Jurnal Kesehatan Andalas 6(1)

Burhannudin, I., Wibowo, B.H., Sidiq, M.N. 2015. Penyuluhan pentingnya sayuran bagi anak-anak di TK Aisyiyah Kwadungan, Trowangsan, Malangjiwan, Colomadu, Karanganyar, Jawa Tengah. WARTA, vol.18, No.1

Dinkes Sukoharjo, 2011. Profil Kesehatan Sukoharjo 2010. Sukoharjo: Dinkes Sukoharjo. 
Geoffrey, D., Graeme, B., Dorsey, B., Mitchell, C., Alessio, F., Olivier, F., et al. 2002. Infectious diarrhea in children : working group report of the first world congress of pediatric gastroenterology, hepatology, and nutrition. Journal of Pediatric Gastroenterology and Nutrition, vol. 35, p.S143-S150

Kemenkes RI. 2016. Data dan Informasi Profil Kesehatan Indonesia 2016. Online : www.depkes.go.id/resources/download/pusdatin, diakses pada Januari 2018

Maryatun. 2008. Entamoeba histolytica : parasit penyebab amebiasis usus dan hepar. Jurnal Kedokteran Syiah Kuala Vol. 8 No. 1.Pp : 39-46

Meningher, T., Boleslavsky, D., Barshack, I., Tabibian-Keissar, H., Kohen, R., Gur-Wahnon, D., et al. 2019. Giardia lamblia miRNAs as a new diagnostic tool for human giardiasis. PloS Negl Trop Dis 13(6)

Rina. 2017. Identifikasi Protozoa Usus dan Bakteri Coliform dari Berbagai Jenis Lalat di Pasar Pasir Gintung Bandar Lampung. Universitas Islam Negeri Raden Intan Lampung. Skripsi.

Rusmartini, T. 2009. Penyakit oleh Protozoa Usus, dalam : Parasitologi edokteran Ditinjau dari Organ Tubuh yang Diserang, editor : Djaenudin Natadisastra dan Ridad Agoes. Jakarta : EGC

Schuster, F.L., Ramirez-Avila, L. 2008. Current world status of Balantidium coli. Clinical Microbiology Reviews, Vol. 21, No. 4, p. 626-638

Soedarto. 2011. Buku Ajar Parasitologi Kedokteran. Jakarta : Sagung Seto

Sutanto, I., Ismid I.S., Sjarifuddin, P.K., Sungkar, S., 2011. Buku Ajar Parasitologi Kedokteran ed 4. Jakarta : Badan Penerbit FK UI

Vivancos, V., Gonzalez-Alvarez, I., Gonzalez-Alvarez, M. 2018. Giardiasis : Characteristics, pathogenesis and new insights about treatment. Curr Top Med Chem, 18(15):1287-1303 
Volume. 1 No. 2 tahun 2020 Nov 2020 - Mei 2021
ISSN (online): 2722-2055 https://jurnal.umj.ac.id/index.php/ASSYIFA
AS-SYIFA: Jurnal Pengabdian dan Pemberdayaan Kesehatan Masyarakat 